\title{
ECONOMIA E COVID-19: EDUCAÇÃO FINANCEIRA NO BRASIL
}

\author{
English title: ECONOMY AND COVID-19: FINANCIAL EDUCATION IN BRAZIL
}

doi>10.33726/discportadmandakediaanais2447-7656v0a2020p06-06

OLIVEIRA, Laura Stephanie ${ }^{1}$ - laura.1094225@discente.uemg.br PESSOA, Marcelo ${ }^{2}$ - iD https://orcid.org/0000-0002-9193-4604

RESUMO: O artigo trata da crise econômica provocada pela pandemia do Covid-19 no Brasil, e de como os brasileiros foram surpreendidos pelo fato, o que claramente prejudicou a condição financeira de parte da população. Tem-se aqui por objetivo, apresentar a relação e influência dos sintomas socioculturais da pandemia como catalisadores de transformações na conduta financeira da população. A metodologia empregada foi a da utilização dos dados coletados digitalmente a partir da pesquisa feita pela Xpeed, disponibilizada pelo Instituto Locomotiva. Justifica a realização de um estudo como este, a oscilação da conduta financeira do brasileiro, a qual tem sido amplamente divulgada na mídia durante $o$ isolamento social. Os resultados parciais apontam que, ainda que o conhecimento financeiro seja limitado, 90\% dos brasileiros disseram ter interesse em aprender mais sobre investimentos e sobre educação financeira. O principal aporte bibliográfico utilizado deriva da matéria referenciada, retirada do site InfoMoney.

PALAVRAS-CHAVE: Educação financeira, crise econômica, pandemia

ABSTRACT: The article deals with the economic crisis caused by the Covid-19 pandemic in Brazil, and how Brazilians were surprised by the fact, which clearly affected the financial condition of part of the population. The objective here is to present the relationship and influence of the social and cultural symptoms of the pandemic as catalysts for changes in the financial conduct of the population. The methodology used was the use of data collected digitally from the research made by Xpeed, made available by the Locomotive Institute. It justifies conducting a study like this, the oscillation of the Brazilian's financial conduct, which has been widely reported in the media during social isolation. The partial results show that, although financial knowledge is limited, $90 \%$ of Brazilians said they were interested in learning more about investments and financial education. The main bibliographic contribution used derives from the referenced material, taken from the InfoMoney website.

KEYWORDS: Financial education, economic crisis, pandemic

\section{REFERÊNCIAS}

YAZBEK, Priscila. Pandemia prejudica o orçamento do brasileiro, mas eleva interesse por educação financeira, diz pesquisa. Disponível em: InfoMoney: https://www.infomoney.com.br/minhas-financas/pandemia-prejudica-o-orcamento-dobrasileiro-mas-eleva-interesse-por-educacao-financeira-diz-pesquisa/. Acesso em 23 de novembro de 2020.

${ }^{1}$ Graduanda em Administração. UEMG - Universidade do Estado de Minas Gerais - Unidade Frutal. Produção científica concebida sob orientação e vinculada à Disciplina de Português, $2^{\circ}$ período de 2020.

${ }^{2}$ Doutor em Letras pela Universidade Estadual de Londrina. Orientador e Docente na UEMG - Unidade Frutal. Departamento de Linguística, Letras, Comunicação e Artes - DLLCA. 